\title{
Dissecting thyroid hormone transport and metabolism in dendritic cells
}

\author{
Nicolás Gigena', Vanina A Alamino', María del Mar Montesinos', Magalí Nazar1, \\ Ruy A Louzada', Simone M Wajner3, Ana L Maia33, Ana M Masini-Repiso', \\ Denise P Carvalho ${ }^{2}$, Graciela A Cremaschi ${ }^{4}$ and Claudia G Pellizas' ${ }^{1}$ \\ 'Centro de Investigaciones en Bioquímica Clínica e Inmunología (CIBICI-CONICET), Facultad de \\ Ciencias Químicas, Universidad Nacional de Córdoba, Córdoba, Argentina \\ 2Instituto de Biofísica Carlos Chagas Filho, Universidade Federal do Rio de Janeiro, Centro de Ciências \\ da Saúde, Rio de Janeiro, Brazil \\ 3Thyroid Unit, Endocrinology Division, Hospital de Clínicas de Porto Alegre, Universidade Federal do Rio \\ Grande do Sul, Porto Alegre, Brazil \\ 4Laboratorio de Neuroinmunomodulación y Oncología Molecular, Instituto de Investigaciones Biomédicas \\ (BIOMED-CONICET), Universidad Católica Argentina, Ciudad Autónoma de Buenos Aires, Argentina
}

Correspondence should be addressed to $C$ G Pellizas

Email claudia@fcq.unc.edu.ar

\begin{abstract}
We reported thyroid hormone (TH) receptor expression in murine dendritic cells (DCs) and 3,5,3'-triiodothyronine $\left(\mathrm{T}_{3}\right)$-dependent stimulation of $\mathrm{DC}$ maturation and ability to develop a Th1-type adaptive response. Moreover, an increased DC capacity to promote antigen-specific cytotoxic T-cell activity, exploited in a DC-based antitumor vaccination protocol, was revealed. However, putative effects of the main circulating $\mathrm{TH}$, L-thyroxine $\left(\mathrm{T}_{4}\right)$ and the mechanisms of $\mathrm{TH}$ transport and metabolism at DC level, crucial events for $\mathrm{TH}$ action at target cell level, were not known. Herein, we show that $\mathrm{T}_{4}$ did not reproduce those registered $\mathrm{T}_{3}$-dependent effects, finding that may reflect a homoeostatic control to prevent unspecific systemic activation of DCs. Besides, DCs express MCT10 and LAT2 TH transporters, and these cells mainly transport $\mathrm{T}_{3}$ with a favored involvement of MCT10 as its inhibition almost prevented $\mathrm{T}_{3}$ saturable uptake mechanism and reduced $\mathrm{T}_{3}$-induced IL-12 production. In turn, DCs express iodothyronine deiodonases type 2 and 3 (D2, D3) and exhibit both enzymatic activities with a prevalence towards TH inactivation. Moreover, $\mathrm{T}_{3}$ increased MCT10 and LAT2 expression and $T_{3}$ efflux from DCs but not $T_{3}$ uptake, whereas it induced a robust induction of D3 with a parallel slight reduction in D2. These findings disclose pivotal events involved in the mechanism of action of THs on DCs, providing valuable tools for manipulating the immunogenic potential of these cells. Furthermore, they broaden the knowledge of the $\mathrm{TH}$ mechanism of action at the immune system network.
\end{abstract}
Key Words
- thyroid hormones (THs)
- triiodothyronine $\left(\mathrm{T}_{3}\right)$
- TH mechanism of action
- dendritic cells (DCs)
- TH transport
- TH metabolism

Journal of Endocrinology (2017) 232, 337-350

\section{Introduction}

Thyroid hormones (THs) are critical regulators of cellular differentiation, growth and metabolism. The thyroid secretes $100 \%$ of circulating thyroxine $\left(\mathrm{T}_{4}\right)$. However, it provides a low percentage of serum levels of the most physiologically active TH: 3,5,3'-triiodothyronine $\left(\mathrm{T}_{3}\right)$, the major part of which is derived from peripheral $5^{\prime}$ deiodination of $\mathrm{T}_{4}$ (Williams \& Bassett 2011).

Cellular activity of THs is classified as genomic (nuclear) and nongenomic (initiated either in the

Published by Bioscientifica Ltd 
cytoplasm or at the plasma membrane). However, the main mechanism of $\mathrm{TH}$ action requires the participation of $\mathrm{T}_{3}$ and its nuclear receptors (TRs): TR $\alpha 1$, TR $\beta 1$, TR $\beta 2$, and TR $\beta 3$, whereas other non- $\mathrm{T}_{3}$-binding isoforms are also expressed (Bernal et al. 2015). It is noteworthy that the action of $\mathrm{TH}$ requires the proper interplay among cellular TH transporters, TH deiodinases and TRs expression (Williams \& Bassett 2011, Kwakkel et al. 2014).

The uptake-efflux of THs by target cells is facilitated by proteins with different specificities for iodothyronine transport. The main TH transporters include monocarboxylate transporters (MCT) 8 and 10, organic anion transporter polypeptides (OATP) 1C1 and large neutral amino acid transporters (LAT) 1 and 2. MCT8, MCT10 and LATs have higher affinity for $\mathrm{T}_{3}$ uptake than $\mathrm{T}_{4}$ (Bernal et al. 2015).

The concentrations of THs at cellular level are regulated by the activity of three selenoproteins termed type 1, 2 and 3 iodothyronine deiodinases (D1, 2 and 3 encoded by Dio 1, 2 and 3 genes). D1 and D2 catalyze the outer ring deiodination that converts $\mathrm{T}_{4}$ to $\mathrm{T}_{3}$, whereas D3 deiodinates the inner ring iodides, thus initiating the conversion of $\mathrm{T}_{4}$ and $\mathrm{T}_{3}$ in inactive metabolites. Therefore, D2 is considered an 'activating' enzyme, responsible for the peripheral production of $50-80 \%$ of the total body pool of $\mathrm{T}_{3}$. Conversely, D3 restrains $\mathrm{T}_{3}$ action in target cells. TH transporters and deiodinases exhibit a particular expression profile that is cellular and metabolic state specific, as well as characteristic in several pathological conditions (Williams \& Bassett 2011, Kwakkel et al. 2014, Bernal et al. 2015).

The effects of THs on several immune cells and their functions have been reported (De Vito et al. 2011, 2012, Cremaschi et al. 2016). However, studies on the impact of THs on the initiation of adaptive immunity at the level of antigen-presenting cells (APCs) are just emerging. We provided the first evidence of the expression of TRs, mainly the $\beta 1$ isoform, and demonstrated that $T_{3}$ contributes to the maturation of the main APC: dendritic cells (DCs). A Th1-lymphocyte $\mathrm{T}$ adaptive response induced by physiologic levels of $\mathrm{T}_{3}$ was also revealed (Mascanfroni et al. 2008). Mechanistically, these effects involved the activation of Akt and NF-kB pathways (Mascanfroni et al. 2010) and were counteracted by glucocorticoids (Montesinos et al. 2012). Moreover, we recently revealed that $T_{3}$ endows DCs with enhanced ability to stimulate cytotoxic T-cell responses with implications in DC-based immunotherapy (Alamino et al. 2015). However, the effect of $\mathrm{T}_{4}$ at $\mathrm{DC}$ level and the mechanisms of $\mathrm{TH}$ entrance and metabolization in DCs were unknown and disclosed in this work. The results obtained unravel new insights into TH action at the initiation of the immune response and provide tools for the manipulation of the potential immunogenicity of DCs, with profound impact on immunotherapy. To the best of our knowledge, this is the first systematic report of both mechanisms fully dissected in a cell from the immune system.

\section{Materials and methods}

\section{Materials}

$\left[{ }^{125} \mathrm{I}\right] \mathrm{T}_{3}$ and $\left[{ }^{125} \mathrm{I}\right] \mathrm{T}_{4}$ were from Perkin Elmer Life and Analytical Sciences (Boston, MA, USA). Nonradioactive iodothyronines and leucine were from Sigma. Materials were from cell culture and of molecular biology grade.

\section{Mice}

Female C57BL/6 mice (B6; H-2b) were obtained from Ezeiza Atomic Center (Argentina). Mice were maintained under specific pathogen-free conditions and used when they were aged 6-10 weeks. Animal protocols were in compliance with the Guide for the Care and Use of Laboratory Animals published by the NIH and the local institutional animal care committee.

\section{DCs preparation and culture}

Immature bone marrow DCs (iDCs) were obtained as described (Mascanfroni et al. 2008). Briefly, bone marrow progenitors were collected from the femurs of 6- to 10-week-old female C57BL/6 mice and cultured in RPMI-1640 10\% fetal calf serum (FCS) depleted of THs by treatment with resin AG-1-X8 (Bio-Rad Laboratories) in the presence of granulocyte-macrophage colony-stimulating factor (GM-CSF) from supernatant of the J558 cell line and fed every 2 days. At day 10 of cell culture, $>85 \%$ of the harvested cells expressed MHC class II, CD40, CD80 and CD11c, but not Gr-1. Immature DCs were cultured with $\mathrm{T}_{3}(5 \mathrm{nM})$ for $18 \mathrm{~h}$ (that induce DC maturation: mDCs) or with $\mathrm{T}_{4}$ at times and concentrations indicated. Parallel cultures were maintained without stimuli as controls. To rule out endotoxin contamination of $\mathrm{T}_{3}$ and $\mathrm{T}_{4}$ preparations, we checked the endotoxin content that raised levels lower than $0.03 \mathrm{IU} / \mathrm{mL}$ (limit of detection) by the Limulus amebocyte lysate assay. 


\section{Flow cytometric analysis}

Intracellular IL-12 and CD11c detection by flow cytometry was performed as previously described (Alamino et al. 2015) using the following fluorochrome-conjugated monoclonal antibodies (mAbs): fluorescein isothiocyanate (FITC)-anti-CD11c and phycoerythrin (PE)-anti-IL-12 (BD Biosciences, San Jose, CA, USA).

\section{Cytokine determination}

IL-12p70 detection was performed in cell culture supernatants using standard capture enzymelinked immunosorbent assays (ELISA), as reported (Montesinos et al. 2012). Briefly, coating antibody included a rat anti-mouse IL-12p70 mAb (clone C15.6, BD Biosciences). Detection antibody included biotinylated rat anti-mouse IL-12p70 mAb (clone C17.8, BD Biosciences). Streptavidin-horseradish peroxidase and 2,2-azino-bis(3ethylbenzthiazoline-6-sulfonic acid) diammonium salt (Sigma) were used as enzyme and substrate, respectively.

\section{Reverse transcription (RT) and polymerase chain reaction (PCR)}

Cells were homogenized with TRIzol (Sigma), and RNA extraction was performed according to the manufacturer's recommended protocol. mRNA was reverse transcribed and amplified by PCR essentially as described (Mascanfroni et al. 2008). Gene-specific primer sets to amplify TH transporters (Mct8, Mct10, Oatp1c1, Lat1 and Lat2) and iodothyronine deiodinases (Dio 1, 2 and 3) mRNAs were from Sigma (Buenos Aires, Argentina, Table 1). Mct8, Oatp1c1, Lat1, Lat2 and Dio1 primers were designed to distinguish cDNA and genomic DNA/pseudogenes linking the sequences of 2 exons and excluding an intron (Kreuzer \& Neece 1999). For Dio 2 and 3 mRNA, as the primers were designed in an exon region, genomic DNA contamination was excluded by performing parallel no RT control reactions.
The expressions of these mRNAs were normalized using $\beta$-actin mRNA. The PCR amplification was performed on an ICycler PCR System (Bio-Rad). The mass of total RNA for RT, the number of cycles and thermal profile for PCR, and $\mathrm{MgCl}_{2}$, primer and dNTP concentrations were selected experimentally (data not shown). RT-PCR products were resolved by electrophoresis in $2 \%$ agarose gels followed by ethidium bromide staining. Specific target amplification was confirmed by automatic sequencing (Macrogen, Seul, Korea).

\section{Quantitative PCR (qPCR)}

qPCR analysis was carried out using an ABI Prism 7500 detection system (Applied Biosystems) and SYBR green chemistry as described (Alamino et al. 2015). qPCR efficiency for each pair of primers was calculated using standard curves generated by serial dilutions of cDNA from DCs. All qPCR efficiencies ranged between $96 \%$ and 102\% in different assays. mRNA levels are shown normalized against the housekeeping gene $\beta$-actin mRNA. We also used TATA box-binding protein and glyceraldehyde 3-phosphate dehydrogenase (GAPDH) to normalize target mRNAs obtaining similar results (data not shown).

\section{Preparation of total cell extracts}

Cells were resuspended in RIPA buffer with protease inhibitors, disrupted by passages through a $25-\mathrm{G}$ needle and incubated on ice followed by removal of DNA and debris by centrifugation. The supernatant was frozen at $-80^{\circ} \mathrm{C}$. Protein concentration was measured by the Bradford method (Bradford 1976).

\section{Western blot analysis}

Total cell lysates of DCs were used for immunodetection of MCT10 (55 kDa), LAT2 (58 kDa), D2 (31 kDa) and D3 $(32 \mathrm{kDa})$ by Western blot analysis performed as described

Table 1 Mouse primers for conventional RT-PCR and RT-qPCR (SYBR GREEN) analysis.

\begin{tabular}{|c|c|}
\hline Name & Primer \\
\hline Mct8 & Forward: CCCATTGCATTTGAGCTGGTG \\
\hline (NM_009197.2) & Reverse: TTGATGCATCAGAGGGACGAAG \\
\hline Mct10 & Forward: CTAGTTGGTCCTCAGGATGCTTC \\
\hline (NM_001114332.1) & Reverse: GGGATTAAACAGAGCACAACACC \\
\hline Oatp1c1 & Forward: GTGGGGACAATGGGATTACC \\
\hline (NM_013797.5) & Reverse: CTTTCTGACACCTGCCCATC \\
\hline Lat1 & Forward: TCAGCTTCTTCAACTGGCTGTG \\
\hline (NM_011404.3) & Reverse: GCTTGTTCTTCCACCAGACACC \\
\hline
\end{tabular}

\begin{tabular}{l} 
Name \\
\hline Lat2 \\
(NM_016972.2) \\
Dio1 \\
(NM_007860.3) \\
Dio2 \\
(NM_010050.2) \\
Dio3 \\
(NM_172119.2)
\end{tabular}

\begin{tabular}{l} 
Primer \\
\hline Forward: GATAGTCCTTCGCTGGAAGAAGC \\
Reverse: GGGTTTGTGTTGCCAGTAGACAC \\
Forward: GTGGTGGACACAATGCAGAAC \\
Reverse: GTGTCTAGGTGGAGTGCAAAGC \\
Forward: GCCACCTGACCACCTTTCA \\
Reverse: CTTGGTTCCGGTGCTTCTTAA \\
Forward: AACTCTAGCAGTTCCGCATATGG \\
Reverse: CCCACCAATTCAGTCACTTGTC
\end{tabular}


(Alamino et al. 2015). Abs against MCT10 (ab171649), LAT2 (ab75610), D2 (ab135711) and D3 (ab82041) (Abcam) were used. $\beta$-actin (Sigma) was used as loading control. To note, positive controls were selected in accordance to the data sheet provided by the supplier, but Western blots lacked a negative control. Signals were detected using the Odyssey Imaging System (LI-COR, Lincoln, NE, USA). Band intensities were evaluated using ImageJ software (NIH).

\section{TH transport experiments}

TH transport through DCs' membranes was evaluated as described (Visser et al. 2009, Loubiere et al. 2012, Zevenbergen et al. 2015). In brief, cells were washed with incubation medium (Dulbecco's PBS containing $0.1 \%$ D-glucose and $0.1 \%$ BSA). Uptake of THs was tested by incubation $(3-90 \mathrm{~min})$ of the cells at $37^{\circ} \mathrm{C}$ with $1 \mathrm{nM}\left(100 \times 10^{5} \mathrm{cpm}\right)\left[{ }^{125 I}\right] \mathrm{T}_{3}$ or $\left.{ }^{[125 I}\right] \mathrm{T}_{4}$ in $1.5 \mathrm{~mL}$ incubation medium. Thereafter, cells were thoroughly washed with TH-free medium, lysed with $0.1 \mathrm{M} \mathrm{NaOH}$ and radioactivity was measured in a $\gamma$-counter. The

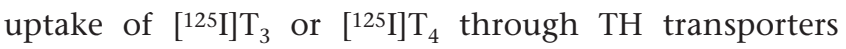
was inhibited by nonradioactive iodothyronines, bromsulfophthalein (BSP, MCT10 inhibitor) and/or leucine (Leu, LAT2 inhibitor) at concentrations previously reported (Visser et al. 2009, Loubiere et al. 2012). The Michaelis-Menten constant $\left(K_{\mathrm{m}}\right)$ and the half maximal inhibitory concentration $\left(\mathrm{IC}_{50}\right)$ were calculated from the GraphPad Prism (GraphPad Software 5.01). Dose-response inhibition curve was obtained by plotting the uptake percentage vs unlabeled THs concentration (Feng et al. 2015).

For measurement of TH efflux of TH transport at DC level, we followed the methods previously described (Visser et al. 2009). Cells were loaded for $30 \mathrm{~min}$ with incubation medium containing $1 \mathrm{nM}\left[{ }^{125} I\right] \mathrm{T}_{3}$ or $\left[{ }^{[25} \mathrm{I}\right] \mathrm{T}_{4}$, briefly washed with incubation medium, and subsequently incubated (0-60 min) with efflux medium (Dulbecco's PBS containing $0.1 \%$ D-glucose and $1 \%$ BSA). After incubation, cells were washed with incubation medium, lysed with $0.1 \mathrm{M} \mathrm{NaOH}$ and radioactivity was measured in a $\gamma$-counter. To allow evaluation of $\mathrm{Na}^{+}$dependence of the $\left[{ }^{125} \mathrm{I}\right] \mathrm{T}_{3}$ or $\left[{ }^{125} \mathrm{I}\right] \mathrm{T}_{4}$ uptake, cells were incubated in a buffer containing $142.9 \mathrm{mM} \mathrm{NaCl}, 4.7 \mathrm{mM} \mathrm{KCl}, 1.2 \mathrm{mM} \mathrm{MgSO}_{4}$, $1.2 \mathrm{mM} \mathrm{KH}_{2} \mathrm{PO}_{4}, 1.8 \mathrm{mM} \mathrm{CaCl}_{2}, 20 \mathrm{mM}$ HEPES and $0.1 \%$ BSA ( $\mathrm{pH}$ 7.4) or in medium in which $\mathrm{Na}^{+}$was replaced with an equimolar concentration of choline (Visser et al. 2009).

\section{Cell death assays}

Cell death by necrosis and/or apoptosis of BSP and Leutreated DCs was measured by flow cytometry using the PE-Annexin V-binding assay and 7-aminoactinomycin $\mathrm{D}$ (7-AAD; BD Biosciences), as we previously described (Alamino et al. 2015).

\section{D2 and D3 activity assays}

The activities of D2 and D3 were evaluated as previously described for other cellular systems (Wajner et al. 2011, Louzada et al. 2014), respectively. For D2 activity determination, DCs' samples $\left(5 \times 10^{6}\right.$ cells/each $)$ were homogenized in $150 \mathrm{mM}$ sodium phosphate buffer containing $1 \mathrm{mM}$ EDTA, $250 \mathrm{mM}$ sucrose and $10 \mathrm{mM}$ DTT (pH 6.9). Forty micrograms of protein of total homogenates from DCs were incubated in duplicate for $3 \mathrm{~h}$ at $37^{\circ} \mathrm{C}$ with $[125 \mathrm{I}] \mathrm{T}_{4}$ previously purified with Sephadex LH-20, $1 \mathrm{mM}$ propylthiouracil (PTU, to inhibit any D1 activity) and $20 \mathrm{mM}$ DTT in $100 \mathrm{mM}$ potassium phosphate buffer $(\mathrm{pH}$ 6.9) containing $1 \mathrm{mMEDTA}$ and $1 \mathrm{nM}^{\mathrm{n}} \mathrm{T}_{4}$ in a final reaction volume of $300 \mu \mathrm{L}$. Specific D2 activity measurements were confirmed by the inhibition of deiodination reaction in the presence of $\mathrm{T}_{4}$ in excess $(100 \mathrm{nM})$. Blank incubations were carried out in the absence of protein. The reaction was stopped at $4^{\circ} \mathrm{C}$ in an ice bath with the addition of $200 \mu \mathrm{L}$ FCS (Gibco) and $100 \mu \mathrm{L}$ trichloroacetic acid $(50 \%, \mathrm{v} / \mathrm{v})$ followed by vigorous agitation. The samples were centrifuged at $10,000 \boldsymbol{g}$ for $3 \mathrm{~min}$, and $360 \mu \mathrm{L}$ of supernatant was collected for the measurement of 125I liberated during the deiodination reaction, using a $\gamma$-counter. D2 activity was expressed as deiodinated $\mathrm{T}_{4}$ in $\mathrm{fmol} / \mathrm{min} / \mathrm{mg}$ protein. Of note is that we used $3^{\prime}-5^{\prime}-\left[{ }^{125} \mathrm{I}\right] \mathrm{T}_{4}$ as substrate for D2 measurements, and thus, only the outer ring deiodination was detected. Regarding D3 activity measurement, cells were homogenized and sonicated with $10 \mathrm{mM}$ Tris- $\mathrm{HCl}, 250 \mathrm{mM}$ sucrose buffer (pH 7.5) and 10 mM DTT. The homogenates were incubated for $1 \mathrm{~h}$ with $\left.200,000 \mathrm{cpm} \mathrm{[}{ }^{125} \mathrm{I}\right] \mathrm{T}_{3}, 2 \mathrm{nM} \mathrm{T}_{3}, 20 \mathrm{mM}$ DTT, and $1 \mathrm{mM}$ PTU. The addition of $200 \mathrm{nM}$ of $\mathrm{T}_{3}$ completely abolished D3 activity in all samples (data not shown). The reaction was stopped by adding $200 \mu \mathrm{L}$ ethanol 95\%, $50 \mu \mathrm{L} \mathrm{NaOH}(0.04 \mathrm{M})$ and $5 \mathrm{mg}$ PTU. Deiodination was determined based on the amount of $\left[{ }^{125 I}\right] \mathrm{T}_{2}$ produced after reaction products separation by paper chromatography. Results were expressed as the fraction of $\mathrm{T}_{2}$ counts minus the nonspecific deiodination (always $<1.5 \%$ ), obtained with the saturating concentration of $\mathrm{T}_{3}(200 \mathrm{nM})$. 
D3 activity was expressed as [125I] $\mathrm{T}_{2}$ in fmol produced/min/ $\mathrm{mg}$ protein. The quantity of protein assayed was adjusted to ensure that $<30 \%$ of the substrate was consumed.

\section{Statistical analysis}

The analysis of intergroup differences (three or more groups) was conducted by one-way analysis of variance (ANOVA), followed by the Student-Newman-Keuls test. For the analysis of differences between two groups, the statistical significance was determined using the Student's $t$ test for unpaired observations. $P$ values less than 0.05 were considered statistically significant. All experiments were performed at least in triplicate.

\section{Results}

\section{$T_{4}$ did not induce DC maturation and function, as $T_{3}$ does}

We demonstrated relevant findings regarding $\mathrm{T}_{3}$ action in the initiation of adaptive immunity (Mascanfroni et al. 2008, 2010, Montesinos et al. 2012, Alamino et al. 2015). However, $\mathrm{T}_{4}$ is the main $\mathrm{TH}$ secreted by the thyroid and the major TH in circulation, fourfold higher considering free hormone levels (Williams \& Bassett 2011). Therefore, the effect of $\mathrm{T}_{4}$ on sensitive DC maturation/function parameters was assayed. For this purpose, murine bone marrow-derived immature DCs (iDCs) were treated with $\mathrm{T}_{4}$ (from sub- to supra-physiological levels, as found in mice circulation), and IL-12 production and secretion were measured following the experimental protocol carried out with $\mathrm{T}_{3}$ (Mascanfroni et al. 2008). As shown in Fig. $1, \mathrm{~T}_{4}$ at $10^{-8}-10^{-6} \mathrm{M}$ for $18 \mathrm{~h}$ did not induce any significant modification in IL-12 production by DCs (Fig. 1A) or IL-12 secreted to the medium (Fig. 1B), as $\mathrm{T}_{3}$ does. Time course studies (18-36h) neither revealed any significant change (Fig. 1C) in IL-12 released. These results show that TH endowment of DCs with enhanced ability to simulate $\mathrm{T}$-cell responses is depending on $\mathrm{T}_{3}$.

\section{MCT10 and LAT2 transporters are expressed in DCs and transport THs, mainly $T_{3}$}

To further delve into TH action at DC level, the study of TH transport across the DC cell membrane became mandatory. At first, we examined the expression of MCT8,
A

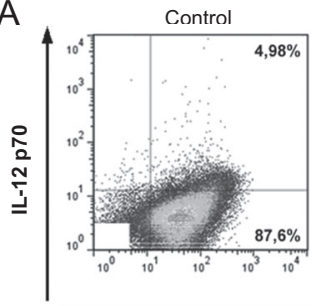

$\mathrm{T}_{3} 5 \mathrm{nM}$

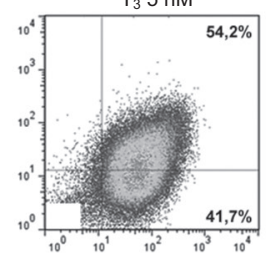

$\mathrm{T}_{4} 10 \mathrm{nM}$

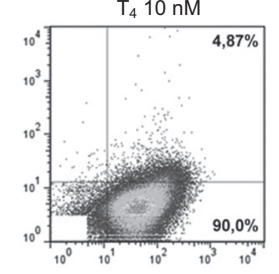

$\mathrm{T}_{4} 100 \mathrm{nM}$

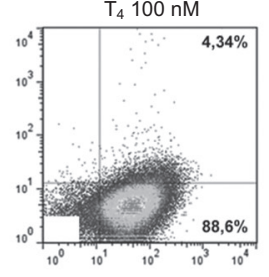

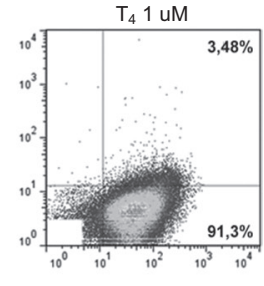

CD11c
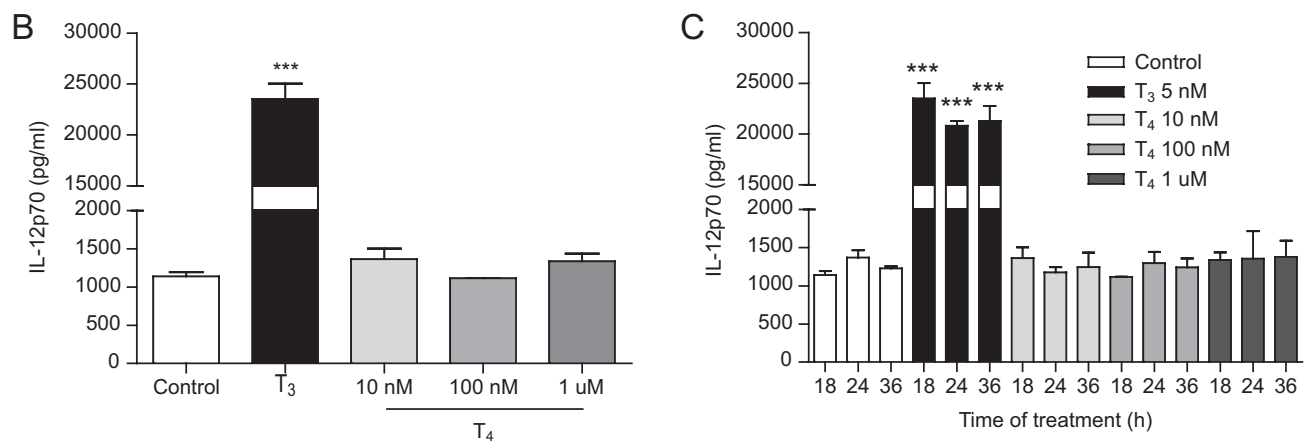

Figure 1

Effects of $\mathrm{T}_{4}$ on IL-12 production and secretion by DCs. (A, B) iDCs were incubated with medium alone (Control), $\mathrm{T}_{3}(5 \mathrm{nM})$ or $\mathrm{T}_{4}$ (10 $\mathrm{nM}, 100 \mathrm{nM}$ or $\left.1 \mathrm{M}\right)$ for $18 \mathrm{~h}$. (A) Intracellular IL-12 was analyzed by flow cytometric analysis of DCs using PE-conjugated anti-IL-12. Representative dot plots of 3 independent experiments conducted in triplicate are shown. (B) IL-12 production was determined in culture supernatants by ELISA. Data are expressed as mean \pm S.D. of a representative experiment of 3 with similar results performed in triplicate. $* * * P<0.001$ vs iDC (Control). (C) Time course study of the effect of $\mathrm{T}_{4}$ on IL-12 secretion. iDCs were incubated with $\mathrm{T}_{3}(5 \mathrm{nM})$ or $\mathrm{T}_{4}(10 \mathrm{nM}, 100 \mathrm{nM}$ and $1 \mathrm{M})$ for 18,24 and $36 \mathrm{~h}$ and IL-12 was measured in the culture media by ELISA. Data are expressed as mean \pm S.D. of a representative experiment of 3 with similar results performed in triplicate. $* * * P<0.001$ vs iDC (Control) at each time of $\mathrm{T}_{3}$ treatment, respectively.

http://joe.endocrinology-journals.org DOI: $10.1530 / \mathrm{JOE}-16-0423$ (c) 2017 Society for Endocrinology Printed in Great Britain
Published by Bioscientifica Ltd 
MCT10, OATP1C1, LAT1 and LAT2 in iDCs, at mRNA and protein levels, by conventional RT-PCR and Western blot, respectively. Figure $2 \mathrm{~A}$ shows that iDCs express mRNAs for Mct10 and Lat2, but not for Mct8, Oatp1c1 or Lat1. These results are in agreement with MCT10 and LAT2 protein expression (Fig. 2B) at comparable levels, although at lesser extent than their positive controls (K562 and HeLa cells). Altogether, these findings highly suggest that MCT10 and/or LAT2 may be involved in TH transport into DCs.

We next attempted to further characterize the process of $\mathrm{TH}$ transport at DC level. We assessed $\left[{ }^{125} \mathrm{I}\right] \mathrm{T}_{3}$ and $\left[{ }^{125} \mathrm{I}\right] \mathrm{T}_{4}(1 \mathrm{nM})$ uptake by iDCs, as previously reported (Visser et al. 2009). Time course analysis demonstrated that both THs were transported by these cells, although cellular uptake of $\left.{ }^{125} \mathrm{I}\right] \mathrm{T}_{3}$ was significantly higher than that of [125I] $\mathrm{T}_{4}$ at all times evaluated, about 5.7 times at $90 \mathrm{~min}$ (Fig. 3A) and revealing that at equal concentrations, the main $\mathrm{TH}$ that gets into DCs is $T_{3}$. Of note is that the rate of [125I] $\mathrm{T}_{3}$ uptake (\%) increased linearly for $30 \mathrm{~min}$ and decreased thereafter, in a similar fashion to other TH-responsive cells (Visser et al. 2009). Afterwards, we evaluated the effects of increasing concentrations of unlabeled iodothyronines on $\left[{ }^{125} \mathrm{I}\right] \mathrm{T}_{3}$ uptake. As depicted in Fig. 3B, a dose-dependent reduction of $\left[{ }^{125 I}\right] \mathrm{T}_{3}$ uptake was observed after the addition of increasing concentrations of unlabeled iodothyronines, $\mathrm{T}_{3}$ or $\mathrm{T}_{4}$. As shown, there are two uptake processes, in agreement with other cellular systems (Visser et al. 2009, Loubiere et al. 2012). In this regard, one of them is not saturated for $\mathrm{T}_{3}$ or $\mathrm{T}_{4}$ concentrations up to $10 \mu \mathrm{M}$, whereas the saturable $\left[{ }^{125} \mathrm{I}\right] \mathrm{T}_{3}$ uptake process shows a $K_{\mathrm{m}}$ value for $\mathrm{T}_{3}$ inhibition of $0.76 \mu \mathrm{M}$ and the $\mathrm{IC}_{50}$ value for $\mathrm{T}_{4}$ inhibition of $\mathrm{T}_{3}$ uptake of $7.78 \mu \mathrm{M}$. Considering that $\left[{ }^{125} \mathrm{I}\right] \mathrm{T}_{4}$ uptake was much lower than $\left[{ }^{125} \mathrm{I}\right] \mathrm{T}_{3}$ uptake (Fig. $3 \mathrm{~B})$, the proper determination of kinetic parameters for $\left.{ }^{[125} \mathrm{I}\right] \mathrm{T}_{4}$ uptake was not possible. As MCT10 and LAT2 are sodium-independent transporters (Halestrap \& Wilson 2012, Kinne et al. 2015), we investigate the dependence of $\mathrm{T}_{3}$ uptake on sodium. Figure 3C shows that replacement of sodium by choline did not induce any significant reduction of $\left[{ }^{[25 I}\right] \mathrm{T}_{3}$ uptake, indicating that $\mathrm{T}_{3}$ transport system does not have any sodium dependence, providing further evidence for MCT10 and/or LAT2 involvement in $\mathrm{T}_{3}$ transport at DC level. Besides, the efflux of ${ }^{[125 I] \mathrm{T}_{3}}$ from DCs has a significantly lower velocity than $\left[{ }^{125} \mathrm{I}\right] \mathrm{T}_{4}$ (Fig. 3D) as about $63 \%$ of cellular $\left[{ }^{125} \mathrm{I}\right] \mathrm{T}_{3}$ remains inside DCs at $60 \mathrm{~min}$ after its uptake vs $32 \%$ of [125I] $\mathrm{T}_{4}$.

To further characterize the $\mathrm{T}_{3}$ uptake system at DC level, it was measured in the presence of MCT10 and LAT2 inhibitors: BSP and Leu, respectively (Loubiere et al. 2012) (Fig. 4A). As shown, BSP significantly reduced 54\% of total $\left[{ }^{125 I}\right] \mathrm{T}_{3}$ uptake, whereas Leu decreased it just $15 \%$, without significant difference from control cells. When BSP and Leu were added together, $\left.{ }^{[125} \mathrm{I}\right] \mathrm{T}_{3}$ uptake
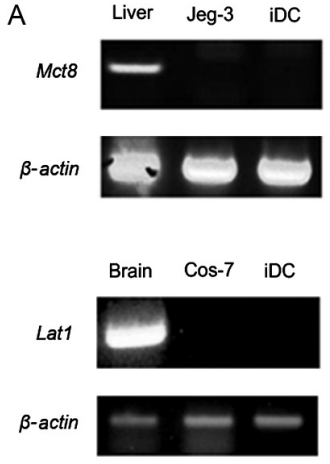

B

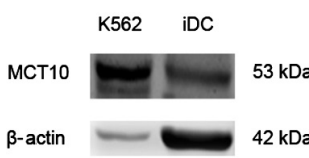

Mct10

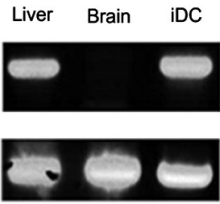

Brain $\quad$ Cos-7 iDC

Lat2

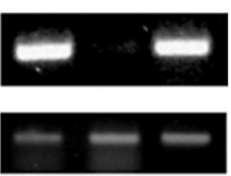

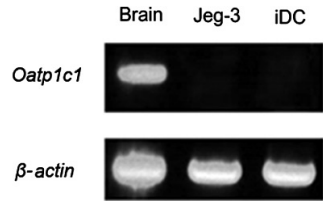

$\beta$-actin

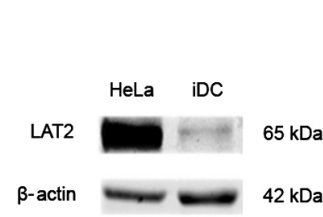

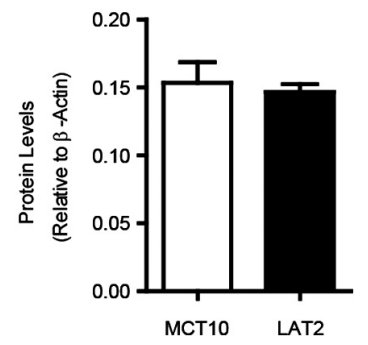

Figure 2

Expression of TH transporters in DCs. (A) Detection of mRNAs for Mct8 (left upper panel), Mct10 (medium upper panel), Oatp1c1 (right upper panel), Lat1 (left lower panel) and Lat2 (medium lower panel) by conventional RT-PCR analysis of total RNA from iDCs. Total RNA from mouse liver, mouse brain, COS-7 and JEG-3 cells were run in parallel as positive (first line) or negative (second line) controls, respectively. $\beta$-actin mRNA was run as a loading control. RT-PCR products were resolved by electrophoresis in $2 \%$ agarose gels followed by ethidium bromide staining. (B) Representative Western blot analysis of total cell lysates from iDCs for MCT10 (left panel) and LAT2 (medium panel). Lysates from K562 and HeLa cells were run in parallel as positive controls of MCT10 and LAT2, respectively. Samples were separated by $10 \%$ SDSPAGE, transferred onto nitrocellulose membranes, and blotted with anti-MCT10 or anti-LAT2 Abs. Equal loading was checked using an anti- $\beta$-actin mAb. Representative blots of 3 independent experiments, conducted in triplicate and with similar results are shown. Right panel shows quantitative analysis of Western blots. Data are expressed as mean \pm S.D. of a representative experiment from 3 with similar results and performed in triplicate. http://joe.endocrinology-journals.org DOI: 10.1530/JOE-16-0423
๑) 2017 Society for Endocrinology Printed in Great Britain 


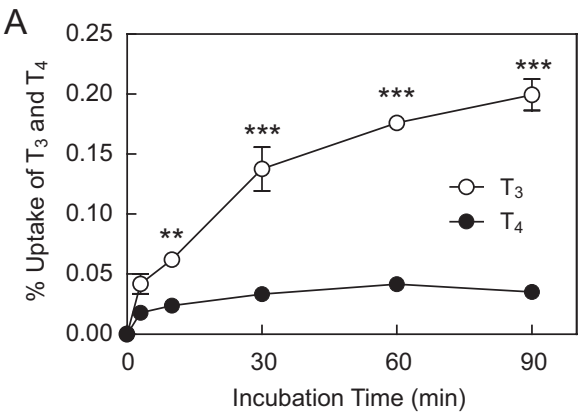

B

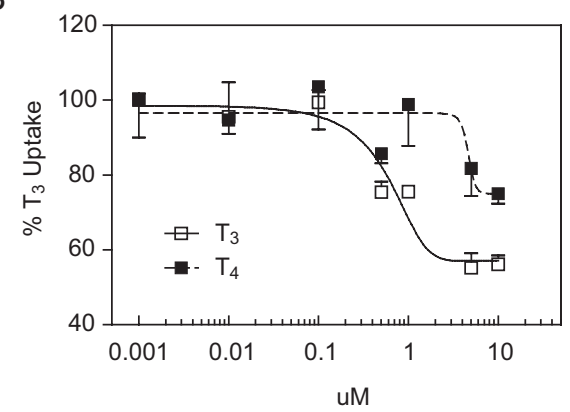

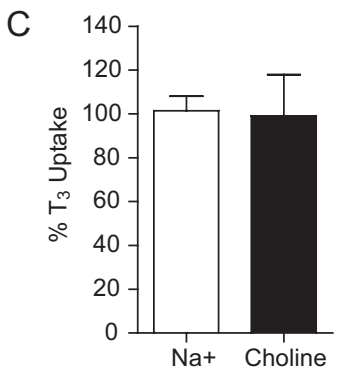

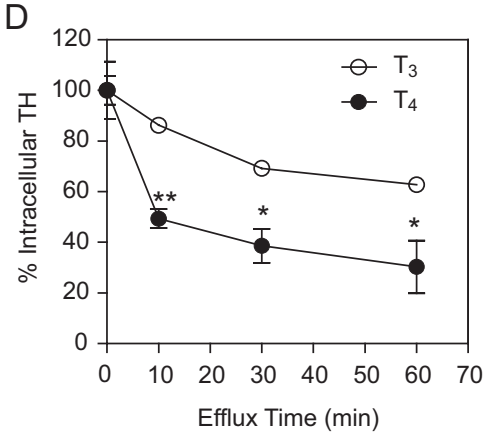

\section{Figure 3}

Characterization of TH transport at DC level. (A) Time course of $1 \mathrm{nM}\left[{ }^{125} \mid\right] \mathrm{T}_{3}(\mathrm{O})$ and $[1251] \mathrm{T}_{4}(\bullet)$ uptake in mice bone marrow-derived iDCs. THs uptake was measured in D-PBS containing $0.1 \%$ glucose and $0.1 \%$ BSA. $* * P<0.01, * * * P<0.001$ vs $\left[{ }^{125} \mid\right] \mathrm{T}_{4}$ at the same time of incubation. (B) Effects of increasing concentrations $(1 \mathrm{nM}-10 \mu \mathrm{M})$ of unlabeled iodothyronines $\left(\square T_{3}, T_{4}\right)$ on $\left[{ }^{125 I}\right] T_{3}$ uptake in iDCs. (C) $\mathrm{Na}^{+}$dependence of $\left.\left[{ }^{125}\right]\right] \mathrm{T}_{3}$ uptake in DCs: Cells were incubated with $1 \mathrm{nM}$ $\left.\left[{ }^{125}\right]\right] \mathrm{T}_{3}$ for $30 \mathrm{~min}$ in sodium chloride medium (white bar) or sodium-free choline medium (black bar). Results are expressed as mean \pm S.D. of the percentage of [125I] $T_{3}$ uptake from cells incubated with $\mathrm{Na}^{+}$containing media. (D) TH efflux from DCs. Cells were incubated for $30 \mathrm{~min}$ with [125|] $\mathrm{T}_{3}$. Afterward, media was removed, cells were thoroughly washed and [125I] $\mathrm{T}_{3}$ measured at 0,30 and $60 \mathrm{~min}$ thereafter. ${ }^{*} P<0.05, * * P<0.01$ vs [125]] $\mathrm{T}_{3}$. Results are expressed as mean \pm S.D. of $\left.\left[{ }^{125}\right]\right] \mathrm{T}_{3}$ uptake at $0 \mathrm{~min}$ and are from a representative experiment from a total of 3 with similar results performed in triplicate. decreased 45\%; however, the difference between BSP and BSP+Leu treatments failed to reach statistical significance. Altogether, these findings are in agreement with $\mathrm{T}_{3}$ inhibition of the saturable process (Fig. 3B), highly suggesting that MCT10 is the main TH transporter. To evaluate the biological significance of MCT10 and LAT2 for $\mathrm{T}_{3}$ action in DCs, IL-12 secretion induced by $\mathrm{T}_{3}$ (Mascanfroni et al. 2008) was measured after concomitant treatment for $18 \mathrm{~h}$ (or not) with both inhibitors. As shown in Fig. $4 \mathrm{~B}$, the addition of Leu in the presence of $\mathrm{T}_{3}$ did not induce any significant change on IL-12 secretion by DCs. However, BSP reduced the effect of $\mathrm{T}_{3}$ by $46 \%$, whereas the presence of both inhibitors together did not diminish IL-12 levels below BSP alone. As treatment with $\mathrm{T}_{3}+\mathrm{BSP}$ did not abolish the effect of $\mathrm{T}_{3}$ on IL-12 secretion by DCs, the amount of $\mathrm{T}_{3}$ that enters DCs by the non-saturable mechanism or by other unknown $\mathrm{TH}$ transporters is enough to induce, although to a lesser extent, the ability of DCs to secrete IL-12. To note, neither BSP nor Leu (at the concentrations assayed) induced any significant
A

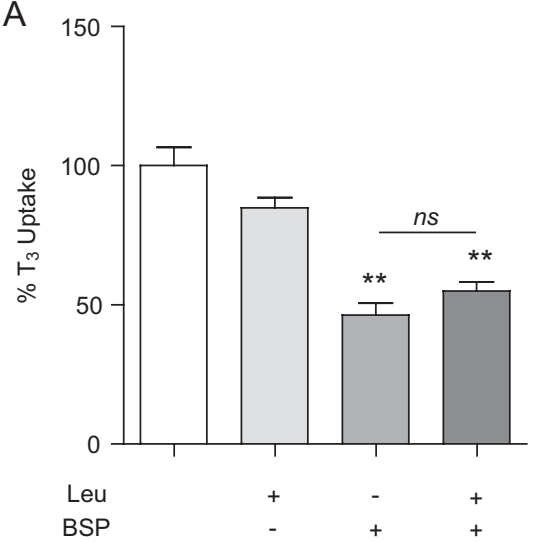

B

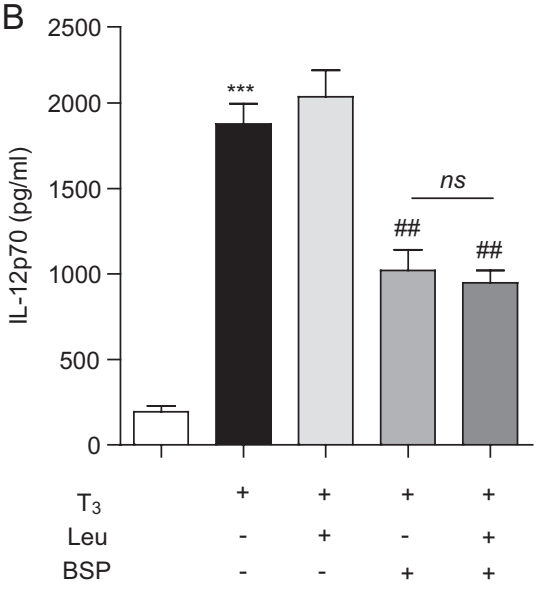

Figure 4

Effect of MCT10 and LAT2 inhibitors on $T_{3}$ uptake (A) and IL-12 secretion (B) by DCs. (A) Effect of $100 \mu \mathrm{M}$ unlabeled competitors: BSP, Leu or both on [125I] $\mathrm{T}_{3}$ uptake. DCs were incubated for $30 \mathrm{~min}$ with $\left[{ }^{125}\right] \mathrm{T}_{3}$ in the absence or the presence of competitors, and net uptake was measured thereafter. Results are expressed as mean \pm S.D. from the percentage of control uptake $\left.\left(1 \mathrm{nM}\left[{ }^{125}\right]\right] \mathrm{T}_{3}\right)$ and are from a representative experiment from a total of 3 with similar results conducted in triplicate. ${ }^{*} P<0.01$ vs control DCs. (B) Effect of $100 \mu \mathrm{M}$ competitors: BSP, Leu or both on $\mathrm{T}_{3}$-induced IL-12 secretion by DCs. DCs were incubated for $18 \mathrm{~h}$ with $\mathrm{T}_{3}$ with or without mentioned inhibitors. IL-12 production was determined in culture supernatants by ELISA. Results are expressed as mean \pm S.D. and are from a representative experiment from a total of 3 with similar results conducted in triplicate. $* * * P<0.001$ vs Control DCs, $\# P<0.01$ vs $\mathrm{T}_{3}$ alone, ns: no significant. 
effect on DC viability over the experimental time (data not shown), measured by the cell death assay. These results highlight the involvement of MCT10 on $\mathrm{T}_{3}$ action at DC level and also disregard LAT2 participation.

\section{Types $\mathbf{2}$ and $\mathbf{3}$ iodothyronine deiodinases are expressed in DCs and metabolize THs}

Considering the pivotal role of $\mathrm{TH}$ metabolism in the action of THs in target cells (Williams \& Bassett 2011), we explored this event in DCs. We first evaluated the expression of TH deiodinase mRNAs (Dio1, Dio2 and Dio3) in iDCs, by conventional RT-PCR. Figure $5 \mathrm{~A}$ shows that iDCs express Dio2 and Dio3, but not Dio1. In turn, these cells also exhibit D2 and D3 protein expression, measured by Western blot (Fig. 5B) that revealed the monomer $31 \mathrm{kDa}$ for D2 and the $65 \mathrm{kDa}$ homodimer native state for D3 (Sagar et al. 2008). Monomeric D3 could not be obtained, even after urea $(6 \mathrm{M})$ treatment of protein lysates. Of note is that D3 protein levels are significantly higher than those of D2 (6.5 fold, Fig. 5B).

To evaluate DC's ability to control intracellular levels of THs, D2 and D3 activities were assessed in iDCs. The activities of D2 and D3 vs protein mass were determined, and results indicated that the increase of D2 activity is linear between 20 and $60 \mu \mathrm{g}$, whereas it is from 80 to $120 \mu \mathrm{g}$ for D3 (data not shown). Therefore, $40 \mu \mathrm{g}$ (for D2)
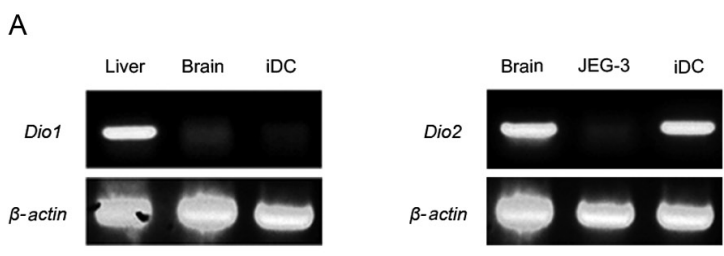

B
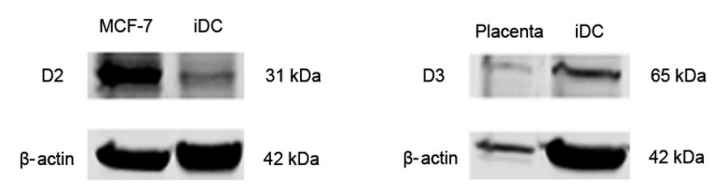

and $100 \mu \mathrm{g}$ (for D3) of total protein extracts were used thereafter. As depicted in Fig. 5C, D2 and D3 activities were revealed in iDCs, although $\left[{ }^{125} \mathrm{I}\right] \mathrm{T}_{3}$ (black bar, D3 activity) was deiodinated at a higher extent than $\left[{ }^{125} \mathrm{I}\right] \mathrm{T}_{4}$ (white bar, D2 activity). The higher D3 than D2 activity (6.6-fold) is quite similar to D3 vs D2 protein expression in iDCs. Altogether, these results suggest that D3 may be preponderant over D2 at least in control (immature) conditions, revealing a major role of iodothyronine inactivation in iDCs.

\section{Regulation of TH transporters and iodothyronine deiodinases by $T_{3}$}

As $\mathrm{T}_{3}$ exhibits profound effects at DC level, inducing phenotypic and functional maturation of iDCs and regulating thereafter adaptive immunity (Mascanfroni et al. 2008, 2010, Montesinos et al. 2012, Alamino et al. 2015), the $\mathrm{T}_{3}$ effect $(5 \mathrm{nM}$ for $18 \mathrm{~h})$ on TH transporters and iodothyronine deiodinases 2 and 3 were evaluated.

As depicted in Fig. 6A, RT-qPCR analysis shows that $\mathrm{T}_{3}$ significantly increased Mct10 and Lat2 mRNAs. These results are in accordance with protein levels of both $\mathrm{TH}$ transporters (Western blot, Fig. 6B). In turn, [125I] $\mathrm{T}_{3}$ and $\left.{ }^{[125}\right] \mathrm{T}_{4}$ uptake by control iDCs and $\mathrm{T}_{3}$-treated cells revealed that although $\mathrm{T}_{3}$ uptake was not modified by $\mathrm{T}_{3}$ treatment
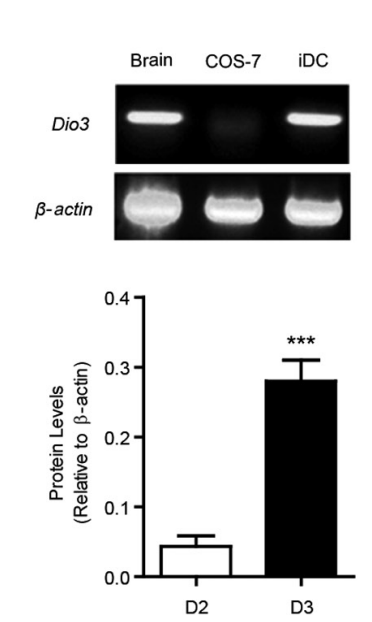

\section{Figure 5}

Expression and activity of iodothyronine deiodinases in iDCs. (A) Detection of mRNA for type 1, 2 and 3 iodothyronine deiodinase mRNAs (Dio1, Dio2 and Dio3) in iDCs by conventional RT-PCR. Total RNA from mouse liver, mouse brain, JEG-3 and COS-7 cells were run in parallel as positive (first line) or negative (second line) controls. $\beta$-actin mRNA is shown as a loading control. RT-PCR products were resolved by electrophoresis in $2 \%$ agarose gels followed by ethidium bromide staining. (B) Representative Western blot analysis for D2 (left panel) and D3 (medium panel) in total cell lysates from iDCs. Lysates from MCF-7 cells (positive control for D2) and rat placenta (positive control for D3) were run in parallel. Samples were separated by $10 \%$ SDS-PAGE, transferred onto nitrocellulose membranes and blotted with anti-D2 or anti-D3 Abs. Equal loading was checked using an anti- $\beta$-actin mAb. Third panel shows densitometric analysis of Western blots. *** $P<0.001$ vs D2 protein expression. (C) D2 and D3 activities in iDCs. Results are indicated as $\mathrm{fmol} \mathrm{T}_{4}$ (for D2) or $\mathrm{T}_{2}$ (for D3)/min/mg protein. Data are expressed as mean \pm s.D. and are from a representative of 3 experiments conducted in triplicate. $* P<0.05$ vs $\mathrm{D} 2$. 
A

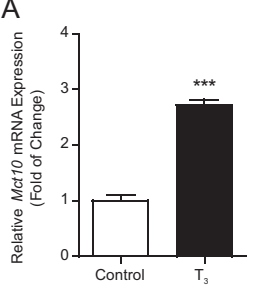

B

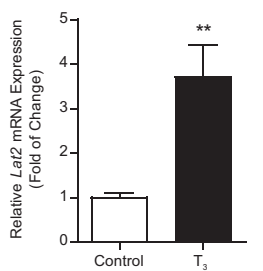

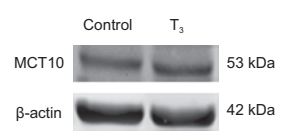

C
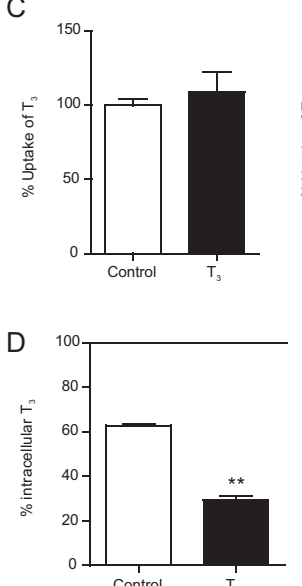
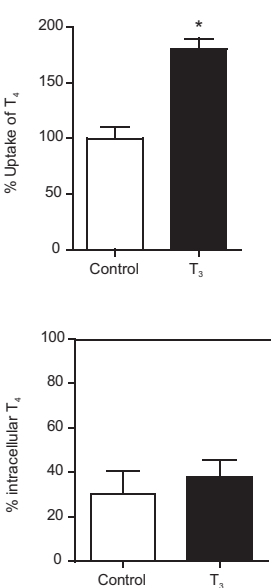

Figure 6

Effect of $\mathrm{T}_{3}$ treatment to iDCs on MCT10 and LAT2 levels. MCT10 and LAT2 at mRNA and protein levels, and $\mathrm{T}_{3}$ or $\mathrm{T}_{4}$ uptake was evaluated in Control (iDC) or iDCs treated with $5 \mathrm{nM} \mathrm{T}$ for $18 \mathrm{~h}\left(\mathrm{~T}_{3}\right)$. (A) RT-qPCR analysis of Mct10 (upper panel) and Lat2 (lower panel) mRNAs. The levels of Mct10 and Lat2 mRNAs were quantified relative to those of $\beta$-actin. Results are indicated as fold of change relative to the mRNA levels of Control iDC. ${ }^{*} P<0.01 ; * * * P<0.001$ vs Control. (B) Western blot analysis of MCT10 and LAT2 protein levels. Left panels show representative blots for MCT10 (upper panel) and LAT2 (lower panel). Equal loading was checked with $\beta$-actin. Right panels exhibit the densitometric analysis of Western blots. Data are expressed as mean \pm S.D. (arbitrary units, $A U$ ) and are from a representative of 3 experiments with similar results and conducted in triplicate. ${ }^{*} P<0.05 ;{ }^{*} P<0.01$, vs Control. (C) Uptake of [125I] $\mathrm{T}_{3}$ (left panel) and [125I] $\mathrm{T}_{4}$ (right panel). ${ }^{*}<0.05$ vs Control. (D) Efflux of [125I] $\mathrm{T}_{3}$ (left panel) and [125I] $\mathrm{T}_{4}$ (right panel) from iDCs and $\mathrm{T}_{3}$-treated DCs. Data are expressed as mean \pm S.D. and are from a representative of 3 experiments performed in triplicate. $* * P<0.01$ vs Control.

of iDC, $\mathrm{T}_{4}$ uptake was significantly increased 2.1-fold (Fig. 6C). On the contrary, $\mathrm{T}_{3}$ efflux was significantly increased in $\mathrm{T}_{3}$-treated DCs when compared to control iDCs (Fig. 6D), whereas $\mathrm{T}_{4}$ efflux was not modified (Fig. 6D).

Regarding $\mathrm{T}_{3}$ effect on iodothyronine deiodinase expression in DCs, $\mathrm{T}_{3}$ significantly augmented Dio3 mRNA expression (1.81 fold increase vs control iDCs, Fig. 7A) and D3 protein levels (3.74 fold increase vs control iDCs, Fig. 7B). In addition, D3 activity was increased by $\mathrm{T}_{3}$ treatment (1.78 fold increase vs control iDCs, Fig. 7C). Conversely, Dio2 mRNA levels tended to decrease in $\mathrm{T}_{3}$ treated DCs, but this failed to reach statistical significance (Fig. 7A). In turn, D2 protein levels were not modified by $\mathrm{T}_{3}$ treatment (Fig. 7B) although D2 activity registered a slight but significant decrease (18\%, Fig. 7C, upper panel).

\section{Discussion}

During the last decade, our findings underscore a novel unrecognized target that regulates DC maturation and function, $\mathrm{T}_{3}$, with outstanding effects at the initiation of adaptive immunity (Mascanfroni et al. 2008, 2010, Montesinos et al. 2012, Alamino et al. 2015). At present, the players involved in $\mathrm{TH}$ actions are well characterized. However, the interaction among them remains to be fully elucidated in a tissue-specific fashion (Brent 2012). As the action of THs may represent an attractive target for rational manipulation of the immunogenicity of DCs, either alone or in combination with other cancer immunotherapeutic strategies (Alamino et al. 2016), the effect of the main circulating $\mathrm{TH}\left(\mathrm{T}_{4}\right)$, as well as the mechanisms of $\mathrm{TH}$ transport and metabolism at DC levels, were disclosed in this work. Noteworthy, both mechanisms were scarcely and only partially studied in few cells from the immune system up to date (Boelen et al. 2008, 2009b, Stevenson et al. 2014), and therefore, this is the first systematic study in the field, conducted at DC level.

In many cellular systems, $\mathrm{T}_{4}$ acts mainly as a prohormone through intracellular $\mathrm{T}_{3}$ conversion to provide the major part of circulating $\mathrm{T}_{3}$ levels and to begin $\mathrm{TH}$ action inside target cells, although rapid nongenomic effects initiated mainly by $\mathrm{T}_{4}$ at the plasma membrane were also reported (Davis et al. 2016). The source of cellular $\mathrm{T}_{3}$, from plasma or from local $\mathrm{T}_{4}$ deiodination by $\mathrm{D} 2$, is extremely variable in different tissues, e.g. 80\% is derived from plasma in cerebral cortex, whereas less than $20 \%$ is from this fraction in kidneys (Dayan \& Panicker 2009). Our results showing that different from $\mathrm{T}_{3}$ (Mascanfroni et al. 2008), treatment of DCs with $\mathrm{T}_{4}$ has no effect on IL-12 production and secretion, gave us the first clue that DC response to

Published by Bioscientifica Ltd 
A
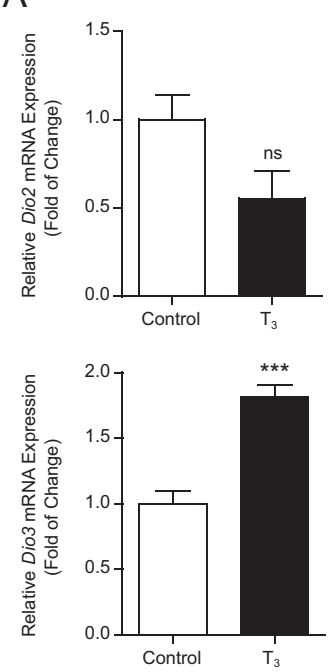

B
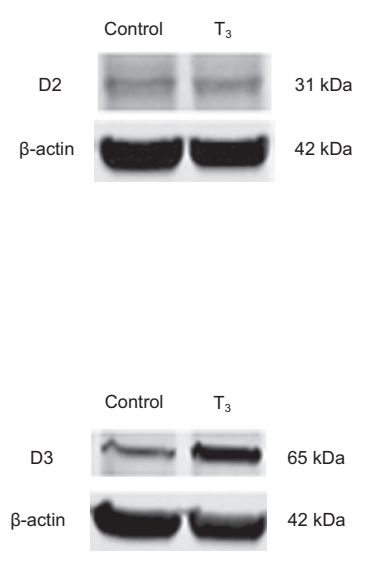

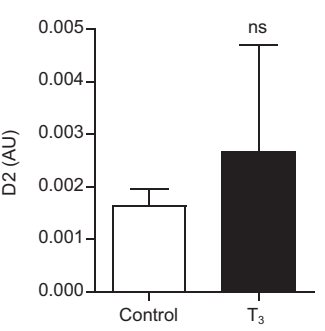

C
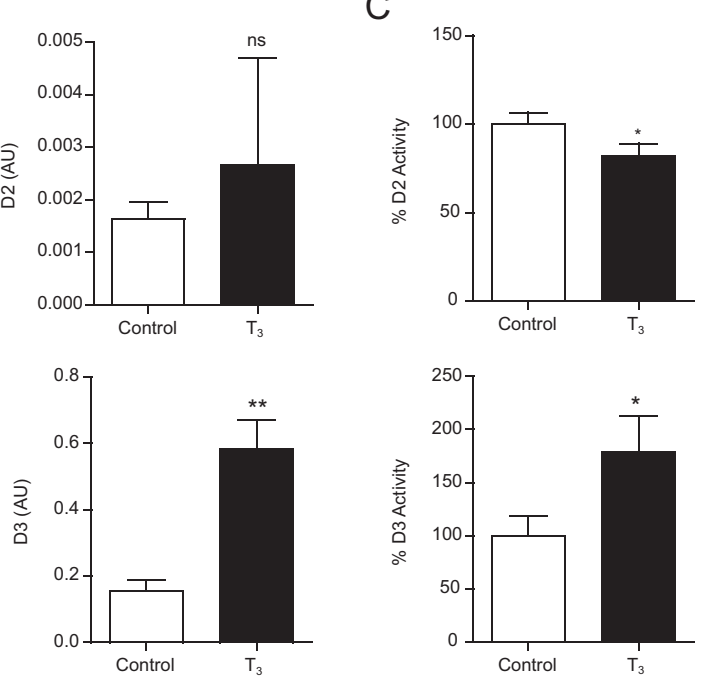

\section{Figure 7}

Effect of $T_{3}$ treatment to iDCs on iodothyronine deiodinases 2 and 3. Dio 2 and 3 mRNAs, and D2 and D3 protein levels as well as D2 and D3 enzyme activities were evaluated in Control (iDC) or $\mathrm{T}_{3}$-treated $\left(\mathrm{T}_{3}\right)$ iDCs. (A) RT-qPCR analysis of Dio2 (upper panel) and Dio3 (lower panel) mRNAs. The levels of Dio2 and Dio3 mRNAs were quantified relative to those of $\beta$-actin. Results are indicated as fold of change relative to the mRNA levels of Control iDC. $* * * P<0.001$, vs Control. (B) Western blot analysis of D2 and D3. Left panels show representative Western blots for D2 (upper panel) and D3 (lower panel). Equal loading was checked with $\beta$-actin. Right panels exhibit the densitometric analysis of Western blots. Data are expressed as mean \pm S.D. (arbitrary units, AU) and are from a representative of 3 experiments with similar results and conducted in triplicate. $* * P<0.01$, vs Control. (C) D2 (upper panel) and D3 (lower panel) enzyme activities. Data are expressed as mean \pm s.D. and are from a representative of 3 experiments performed in triplicate. ${ }^{*} P<0.05$ vs Control.

TH may be due, at least in its major part, directly by $\mathrm{T}_{3}$ action. In some tissues, like the central nervous system, the $\mathrm{T}_{3}$ derived from $\mathrm{T}_{4}$ deiodination also acts in other cells, different from those where it was produced (St Germain et al. 2009). Therefore, although $\mathrm{T}_{4}$ is the major circulating $\mathrm{TH}, \mathrm{T}_{3}$ may also be supplied to DCs from other neighbor cells in their sites of maturation, e.g. lymph nodes and spleen. Considering the crucial reported events induced by $\mathrm{T}_{3}$ on DC characteristics and function (Mascanfroni et al. 2008, Alamino et al. 2015), this postulate seems rational to restrain unspecific activation of DCs in circulation. Moreover, as the biological activity of THs is dependent on the intracellular $\mathrm{T}_{3}$ concentration, which is importantly controlled by TH transport across DCs' membranes and TH metabolism inside target cells (Bernal et al. 2015), further results from this work shed light on both events at DC level, crucial for the fate of the immune system exposed to pathogens or damage signals.

Results show that both MCT10 and LAT2 TH transporters are expressed at mRNA and protein levels in DCs. It was reported that MCT10 is as active as MCT8 for $\mathrm{TH}$ transport (Friesema et al. 2008), the main $\mathrm{TH}$ transporter and most studied due to its brain expression leading to the severe Allan-Herndon-Dudley syndrome when its gene is mutated. Remarkably, although scarce information about $\mathrm{TH}$ transporter expression in immune cells is found, the macrophage cell line RAW264.7 also expresses Mct10 (at mRNA level) but not Mct8 or Oatp1c1 (Kwakkel et al. 2014), in consonance with our results. Noteworthy, macrophages are phylogenetically and functionally related to DCs and it was reported that mice macrophages also exert $\mathrm{T}_{3}$-dependent effects (Perrotta et al. 2013), although TH transport has not been evaluated in these cells yet.

Further analysis of $\mathrm{TH}$ transport mechanism revealed that DCs are more effective in transporting $\mathrm{T}_{3}$ than $\mathrm{T}_{4}$, in agreement with MCT10 and LAT2 expression and regarding their iodothyronine transport preference (Friesema et al. 2008, Loubiere et al. 2012, Schweizer et al. 2014). In accordance, our results show that $T_{3}$ uptake in DCs is sodium independent (Halestrap \& Wilson 2012, Kinne et al. 2015).

Regarding the kinetic characteristics of TH transport, we registered a saturable and a non-saturable component, in tight agreement to $\mathrm{TH}$ transport in other cells (Visser et al. 2009, Loubiere et al. 2012). It was suggested that the latter may reflect iodothyronine partitioning in the cell membrane and/or an unknown transporter system with $K_{\mathrm{m}}$ values in the millimolar range (Visser et al. 2009). When unlabeled $T_{3}$ is added, the saturable process

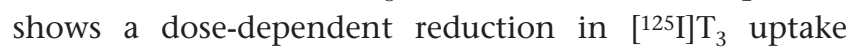

Published by Bioscientifica Ltd. 
with an apparent $K_{\mathrm{m}} 10$ times below the concentration of $\mathrm{T}_{4}$ needed to inhibit $50 \%$ of this uptake $(0.76 \mu \mathrm{M}$ vs $7.78 \mu \mathrm{M})$. These kinetic results provide more evidence to the preferable transport of $\mathrm{T}_{3}$ over $\mathrm{T}_{4}$ at $\mathrm{DC}$ level, and give an additional support to the undetectable effect of $\mathrm{T}_{4}$ on DC function.

Results of the study of $\mathrm{T}_{3}$ transport in DCs in the presence of selective MCT10 and LAT2 inhibitors strengthen the main role of MCT10 in $\mathrm{T}_{3}$ transport in DCs. In agreement, it was reported that LATs exhibit lower affinity than MCTs to transport THs (Friesema et al. 2005) and a recent report revealed that LAT2 exhibits favored affinity for 3,3'-diiodothyronine ( $\left.T_{2}\right)$, less for $T_{3}$ and no affinity for $\mathrm{T}_{4}$ (Kinne et al. 2015), reinforcing the evidence that LAT2 is not compelling for $\mathrm{T}_{3}$ crossing through DC's membrane. Noteworthy, it was reported that MCT10 transports $\mathrm{T}_{3}$ and $\mathrm{T}_{4}$ in and out of cells (Friesema et al. 2008), but it was suggested that it plays a prominent role in $\mathrm{T}_{3}$ efflux (Muller et al. 2014). Considering MCT10 preference for $\mathrm{T}_{3}$ transport, the higher efflux of $\mathrm{T}_{4}$ than $\mathrm{T}_{3}$ out of DCs may be due to other modulators of $\mathrm{TH}$ mechanism of action inside the cell, like the cytoplasmic $\mathrm{T}_{3}$-binding protein or $\mu$-crystallin: CRYM, which binds $\mathrm{T}_{3}$ with higher affinity than $\mathrm{T}_{4}$ and is a regulator of intracellular $\mathrm{T}_{3}$ bioavailability (Suzuki et al. 2007). Remarkably, the marked reduction of IL-12 secretion from DCs exposed to $\mathrm{T}_{3}+\mathrm{BSP}$ over $\mathrm{T}_{3}$ alone reinforces and gives functional support for MCT10's prominent role on $\mathrm{T}_{3}$ transport in DCs.

Although both Mct10 and Lat2 mRNA and protein levels were increased by $\mathrm{T}_{3}$ treatment of DCs, $\mathrm{T}_{3}$ efflux velocity (but not $\mathrm{T}_{3}$ uptake) was augmented. These findings may respond to the preferable role of MCT10 on $\mathrm{T}_{3}$ efflux (Muller et al. 2014). Conversely, $\mathrm{T}_{4}$ uptake was increased by $\mathrm{T}_{3}$-treated DCs. Although under this circumstance, $\mathrm{T}_{4}$ entry to DCs may be favored as a compensatory mechanism to counteract the fall in $\mathrm{T}_{3}$ intracellular level, the amount of $\mathrm{T}_{4}$ uptake is significantly lesser than that of $T_{3}$. Overall, these findings would be involved in $T_{3}$ clearance from DCs and sustain a homeostatic mechanism to restrain $\mathrm{TH}$ action after DC activation.

Although TH cellular concentrations are variable depending on the specific metabolic state, this situation does not impact at plasma view point as $\mathrm{TH}$ serum levels hardly fluctuate. Therefore, by a particular modulation of deiodinase expression and activity at cellular level, TH action is finely controlled (Bianco 2013). Although this mechanism should also operate at TH-responsive immune-type cells, just the expressions of deiodinases were reported in some cell types. These include D3 protein expression in granulocytes and macrophages from a rat model of experimental allergic encephalomyelitis (Boelen et al. 2009a), D3 immunoreactivity in inflammatory cells surrounding a local abscess induced by turpentine injection to mice (Boelen et al. 2008), Dio2 mRNA expression at baseline levels in the macrophage cell line RAW264.7 with Dio1 and Dio3 mRNAs under the limit of detection (Kwakkel et al. 2014), and Dio2 and Dio3 mRNA expression in hamster leukocytes (Stevenson et al. 2014). However, as far as we know, the activities of deiodinases were not reported in any immune-type cell. As for $\mathrm{TH}$ transport, our results provide the first report of TH metabolism in murine DCs, covering the whole metabolic process from the expressions and the activities of iodothyronine deiodinases, to the regulation by $\mathrm{T}_{3}$.

Our results showing iodothyronine deiodinase expression in DCs for types 2 and 3 but not for type 1 is not surprising as it resembles the profile of many TH-responsive cells since both D2 and D3 are mainly involved in the control of TH action at cellular level (Bianco 2013). Conversely, D1, a high $\mathrm{Km}$ enzyme $\left(10^{-7}-10^{-6} \mathrm{M}\right)$, mainly contributes to circulating $\mathrm{T}_{3}$ levels and acts as a scavenging enzyme (Williams \& Bassett 2011, Maia et al. 2011, Darras et al. 2015). Moreover, as D1 is anchored at the plasma membrane and exhibits low affinity for $T_{4}, T_{3}$ generated at this level diffuses rapidly from the cell to the plasma without significant modifications of intracellular levels of $\mathrm{T}_{3}$ (Gereben et al. 2015). Noteworthy, D3 protein levels and enzyme activity are greater than D2 in DCs. Considering both enzymes share the same low $\mathrm{Km}$ in the nM range (Williams \& Bassett 2011) but D3 has a longer half-life than D2 (Bianco \& Kim 2006), a higher role of $\mathrm{T}_{3}$ inactivation by $\mathrm{D} 3$ than $\mathrm{T}_{3}$ intracellular generation by $\mathrm{D} 2$ activity on $\mathrm{T}_{4}$ is suggested. These results seem expectable due to the scarce $\mathrm{T}_{4}$ uptake by the cell and point out another step of cellular control of the active $\mathrm{TH}\left(\mathrm{T}_{3}\right)$ in DCs, favoring its inactivation. As D3 also catalyzes $\mathrm{T}_{4}$ inactivation rendering the inactive iodothyronine metabolite: $\mathrm{rT}_{3}$, the little amount of $\mathrm{T}_{4}$ entering DCs may be sensitive to inactivation. This mechanism together with the little $\mathrm{T}_{4}$ uptake by DCs may collaborate to render the lack of $\mathrm{T}_{4}$ effect at DC level. These results are of relevance since these mechanisms may be involved in the control of $\mathrm{T}_{3}$ action at DCs to avoid the perpetuation of the proinflammatory response induced through the Th1 profile and cytotoxic T-cell activity triggered by $\mathrm{T}_{3}$ (Mascanfroni et al. 2008, Alamino et al. 2015). Besides, taking together the results showing low $\mathrm{T}_{4}$ uptake by DCs and reduced TH activation by $\mathrm{D} 2$ inside the cell, suggest that $\mathrm{T}_{3}$ may be supplied to DCs by the extracellular medium and/or by D2 activity

Published by Bioscientifica Ltd. 
on $\mathrm{T}_{4}$ at neighboring cells in their activation sites ( $\mathrm{St}$ Germain et al. 2009). The disclosure of this issue exceeds the objective of this work, but since DCs are expected to be in an immature state in circulation, it may be hypothesized that this second source of $T_{3}$ is of enough magnitude to modulate DC functioning and plays an important role to control the precise place of DC maturation.

Results showing that the expected effect of $\mathrm{T}_{3}$ on the increased expression and activity of D3 was more evident than the reduction of D2 in DCs, indicate that the cellular activity of $\mathrm{T}_{3}$ must be finely tuned in these cells. These results are in agreement with many authors (Bianco et al. 2002, Darras et al. 2015) that reported that fluctuations in $\mathrm{T}_{4}$ and $\mathrm{T}_{3}$ concentrations lead to homeostatic, reciprocal changes in the activity of $\mathrm{D} 2$ and D3. In fact, as $\mathrm{T}_{3}$ concentrations increase, expression of Dio3 is upregulated, increasing $\mathrm{T}_{3}$ clearance, whereas the expression of Dio 2 is just modestly downregulated, decreasing $\mathrm{T}_{3}$ production.

Worthy to be discussed, $\mathrm{T}_{3}$ regulation of $\mathrm{TH}$ transporter and deiodinase expressions and activities may be the result of its known regulatory action on $\mathrm{TH}$ economy in target cells, depending on the physiological or pathological condition (Bianco 2013). However, an action of $\mathrm{T}_{3}$ due to its role on DCs' maturation and function is also expected. Therefore, the results obtained in this work may be the result of both mechanisms. As different stimuli exert specific actions on DCs' characteristics and functioning, as well as particular effects on the ability of these cells to develop adaptive responses (Walsh \& Mills 2013, Kudo et al. 2013), the disclosure of effects of many other DCs' stimulators on TH transporter and deiodinase expressions and activities, exceeds the goal of this manuscript and is being addressed in ongoing research.

Previously, we reported that $T_{3}$ increased TR $\beta 1$ expression in DCs through NFkB-positive action on the transcription of its gene (Mascanfroni et al. 2010) and that TR $\beta 1$ is essential for $\mathrm{T}_{3}$ action in vitro (Mascanfroni et al. 2010) and in vivo (Alamino et al. 2015). Altogether, $T_{3}$ action on TH transport (uptake-efflux), iodothyronine deiodinases and TR $\beta 1$, may act coordinately to regulate $\mathrm{TH}$ action within the cell in a balanced fashion and depending on the functional requirements of DCs during different physiopathological conditions.

In conclusion, our results underscore in more detail the action of THs at DC level, revealing the pivotal role of $\mathrm{T}_{3}$ over $\mathrm{T}_{4}$ and disclosing the mechanisms of $\mathrm{TH}$ transport and iodothyronine deiodination in these cells. They also broaden the knowledge of the effect of THs at the initiation of the immune response and their role directing adaptive immunity through $\mathrm{T}_{3}$ actions on DCs, with profound implications in immunopathology, including cancer and autoimmune manifestations of the thyroid gland at the crossroads of the immune and endocrine systems. Noteworthy, these results are relevant regarding the recorded effects of $\mathrm{T}_{3}$ on DC functioning as the knowledge of TH transport and metabolism in DCs provides valuable tools for manipulating the immunogenic potential of DCs to positively regulate the development of protective immunity or negatively control the generation of autoimmune thyroid inflammation.

\section{Declaration of interest}

The authors declare that there is no conflict of interest that could be perceived as prejudicing the impartiality of the research reported.

\section{Funding}

This study was supported by grants from Agencia Nacional de Promoción Científica y Tecnológica (ANPCyT, PICT-2008-0890 and PICT-2013-0638), Consejo Nacional de Investigaciones Científicas y Técnicas (CONICET, PIP 2014-2012GI), Secretaría de Ciencia y Tecnología de la Universidad Nacional de Córdoba (SeCyT, 2012-2013 and 2014-2015), and Fundación Sales (2014-2015), from Argentina, Conselho Nacional de Pesquisa from Brazil (CNPq, 2014) and The World Academy of Sciences (TWAS, 2014).

\section{Acknowledgments}

The authors thank Paula Abadie, Pilar Crespo, Alejandra Romero and Laura Gatica for technical assistance in flow cytometry analysis and cell culture and Fabricio Navarro, Diego Luti, Victoria Blanco and Carolina Florit for helping in animal care and management.

\section{References}

Alamino VA, Mascanfroni ID, Montesinos MM, Gigena N, Donadio AC, Blidner AG, Milotich SI, Cheng SY, Masini-Repiso AM, Rabinovich GA, et al. 2015 Antitumor responses stimulated by dendritic cells are improved by triiodothyronine binding to the thyroid hormone receptor beta. Cancer Research 75 1265-1274. (doi:10.1158/0008-5472. CAN-14-1875)

Alamino VA, Montesinos MM, Rabinovich GA \& Pellizas CG 2016 The thyroid hormone triiodothyronine reinvigorates dendritic cells and potentiates anti-tumor immunity. Oncoimmunology 5 e1064579. (doi:10.1080/2162402X.2015.1064579)

Bernal J, Guadano-Ferraz A \& Morte B 2015 Thyroid hormone transporters-functions and clinical implications. Nature Reviews Endocrinology 11 690. (doi:10.1038/nrendo.2015.186)

Bianco AC 2013 Cracking the code for thyroid hormone signaling. Transactions of the American Clinical and Climatological Association 124 26-35.

Bianco AC \& Kim BW 2006 Deiodinases: implications of the local control of thyroid hormone action. Journal of Clinical Investigation 116 2571-2579. (doi:10.1172/JCI29812)

Bianco AC, Salvatore D, Gereben B, Berry MJ \& Larsen PR 2002 Biochemistry, cellular and molecular biology, and physiological roles http://joe.endocrinology-journals.org DOI: $10.1530 / J O E-16-0423$ (c) 2017 Society for Endocrinology Printed in Great Britain
Published by Bioscientifica Ltd 
of the iodothyronine selenodeiodinases. Endocrine Reviews 23 38-89. (doi:10.1210/edrv.23.1.0455)

Boelen A, Boorsma J, Kwakkel J, Wieland CW, Renckens R, Visser TJ, Fliers E \& Wiersinga WM 2008 Type 3 deiodinase is highly expressed in infiltrating neutrophilic granulocytes in response to acute bacterial infection. Thyroid 18 1095-1103. (doi:10.1089/thy.2008.0090)

Boelen A, Kwakkel J, Chassande O \& Fliers E 2009a Thyroid hormone receptor beta mediates acute illness-induced alterations in central thyroid hormone metabolism. Journal of Neuroendocrinology 21 465-472. (doi:10.1111/j.1365-2826.2009.01863.x)

Boelen A, Mikita J, Boiziau C, Chassande O, Fliers E \& Petry KG $2009 b$ Type 3 deiodinase expression in inflammatory spinal cord lesions in rat experimental autoimmune encephalomyelitis. Thyroid 19 1401-1406. (doi:10.1089/thy.2009.0228)

Bradford MM 1976 A rapid and sensitive method for the quantitation of microgram quantities of protein utilizing the principle of protein-dye binding. Analytical Biochemistry 72 248-254. (doi:10.1016/00032697(76)90527-3)

Brent GA 2012 Mechanisms of thyroid hormone action. Journal of Clinical Investigation 122 3035-3043. (doi:10.1172/JCI60047)

Cremaschi GA, Cayrol F, Sterle HA, Diaz Flaque MC \& Barreiro Arcos ML 2016 Thyroid hormones and their membrane receptors as therapeutic targets for T cell lymphomas. Pharmacological Research 109 55-63. (doi:10.1016/j.phrs.2016.02.001)

Darras VM, Houbrechts AM \& Van Herck SL 2015 Intracellular thyroid hormone metabolism as a local regulator of nuclear thyroid hormone receptor-mediated impact on vertebrate development. Biochimica et Biophysica Acta 1849 130-141. (doi:10.1016/j.bbagrm.2014.05.004)

Davis PJ, Goglia F \& Leonard JL 2016 Nongenomic actions of thyroid hormone. Nature Reviews Endocrinology 12 111-121. (doi:10.1038/ nrendo.2015.205)

Dayan CM \& Panicker V 2009 Novel insights into thyroid hormones from the study of common genetic variation. Nature Reviews Endocrinology 5 211-218. (doi:10.1038/nrendo.2009.19)

De Vito P, Incerpi S, Pedersen JZ, Luly P, Davis FB \& Davis PJ 2011 Thyroid hormones as modulators of immune activities at the cellular level. Thyroid 21 879-890. (doi:10.1089/thy.2010.0429)

De Vito P, Balducci V, Leone S, Percario Z, Mangino G, Davis PJ, Davis FB, Affabris E, Luly P, Pedersen JZ, et al. 2012 Nongenomic effects of thyroid hormones on the immune system cells: New targets, old players. Steroids 77 988-995. (doi:10.1016/j.steroids.2012.02.018)

Feng X, Wang X, Liu Y \& Di X 2015 Linarin inhibits the acetylcholinesterase activity in-vitro and ex-vivo. Iranian Journal of Pharmaceutical Research 14 949-954.

Friesema EC, Jansen J \& Visser TJ 2005 Thyroid hormone transporters. Biochemical Society Transactions 33 228-232. (doi:10.1042/BST0330228)

Friesema EC, Jansen J, Jachtenberg JW, Visser WE, Kester MH \& Visser TJ 2008 Effective cellular uptake and efflux of thyroid hormone by human monocarboxylate transporter 10. Molecular Endocrinology 22 1357-1369. (doi:10.1210/me.2007-0112)

Gereben B, McAninch EA, Ribeiro MO \& Bianco AC 2015 Scope and limitations of iodothyronine deiodinases in hypothyroidism. Nature Reviews Endocrinology 11 642-652. (doi:10.1038/nrendo.2015.155)

Halestrap AP \& Wilson MC 2012 The monocarboxylate transporter family - role and regulation. IUBMB Life 64 109-119. (doi:10.1002/ iub.572)

Kinne A, Wittner M, Wirth EK, Hinz KM, Schulein R, Kohrle J \& Krause G 2015 Involvement of the L-type amino acid transporter Lat 2 in the transport of 3,3'-diiodothyronine across the plasma membrane. European Thyroid Journal 4 42-50. (doi:10.1159/000381542)

Kreuzer KN \& Neece SH 1999 Purification of the bacteriophage T4 type II DNA topoisomerase. Methods in Molecular Biology 94 171-177. (doi:10.1385/1-59259-259-7:171)

Kudo M, Ishigatsubo Y \& Aoki I 2013 Pathology of asthma. Frontiers in Microbiology 4 263. (doi:10.3389/fmicb.2013.00263)
Kwakkel J, Surovtseva OV, de Vries EM, Stap J, Fliers E \& Boelen A 2014 A novel role for the thyroid hormone-activating enzyme type 2 deiodinase in the inflammatory response of macrophages. Endocrinology 155 2725-2734. (doi:10.1210/en.2013-2066)

Loubiere LS, Vasilopoulou E, Glazier JD, Taylor PM, Franklyn JA, Kilby MD \& Chan SY 2012 Expression and function of thyroid hormone transporters in the microvillous plasma membrane of human term placental syncytiotrophoblast. Endocrinology 153 6126-6135. (doi:10.1210/en.2012-1753)

Louzada RA, Santos MC, Cavalcanti-de-Albuquerque JP, Rangel IF, Ferreira AC, Galina A, Werneck-de-Castro JP \& Carvalho DP 2014 Type 2 iodothyronine deiodinase is upregulated in rat slow- and fast-twitch skeletal muscle during cold exposure. American Journal of Physiology: Endocrinology and Metabolism 307 E1020-E1029. (doi:10.1152/ajpendo.00637.2013)

Maia AL, Goemann IM, Meyer EL \& Wajner SM 2011 Deiodinases: the balance of thyroid hormone: type 1 iodothyronine deiodinase in human physiology and disease. Journal of Endocrinology 209 283-297. (doi:10.1530/JOE-10-0481)

Mascanfroni I, Montesinos Mdel M, Susperreguy S, Cervi L, Ilarregui JM, Ramseyer VD, Masini-Repiso AM, Targovnik HM, Rabinovich GA \& Pellizas CG 2008 Control of dendritic cell maturation and function by triiodothyronine. FASEB Journal 22 1032-1042. (doi:10.1096/fj.078652com)

Mascanfroni ID, Montesinos Mdel M, Alamino VA, Susperreguy S, Nicola JP, Ilarregui JM, Masini-Repiso AM, Rabinovich GA \& Pellizas CG 2010 Nuclear factor (NF)-kappaB-dependent thyroid hormone receptor beta1 expression controls dendritic cell function via Akt signaling. Journal of Biological Chemistry 285 9569-9582. (doi:10.1074/jbc.M109.071241)

Montesinos MM, Alamino VA, Mascanfroni ID, Susperreguy S, Gigena N, Masini-Repiso AM, Rabinovich GA \& Pellizas CG 2012 Dexamethasone counteracts the immunostimulatory effects of triiodothyronine (T3) on dendritic cells. Steroids 77 67-76. (doi:10.1016/j.steroids.2011.10.006)

Muller J, Mayerl S, Visser TJ, Darras VM, Boelen A, Frappart L, Mariotta L, Verrey F \& Heuer H 2014 Tissue-specific alterations in thyroid hormone homeostasis in combined Mct10 and Mct8 deficiency. Endocrinology 155 315-325. (doi:10.1210/en.2013-1800)

Perrotta C, Buldorini M, Assi E, Cazzato D, De Palma C, Clementi E \& Cervia D 2013 The thyroid hormone triiodothyronine controls macrophage maturation and functions: protective role during inflammation. American Journal of Pathology 184 230-247. (doi:10.1016/j.ajpath.2013.10.006)

Sagar GD, Gereben B, Callebaut I, Mornon JP, Zeold A, CurcioMorelli C, Harney JW, Luongo C, Mulcahey MA, Larsen PR, et al. 2008 The thyroid hormone-inactivating deiodinase functions as a homodimer. Molecular Endocrinology 22 1382-1393. (doi:10.1210/ me.2007-0490)

Schweizer U, Johannes J, Bayer D \& Braun D 2014 Structure and function of thyroid hormone plasma membrane transporters. European Thyroid Journal 3 143-153. (doi:10.1159/000367858)

St Germain DL, Galton VA \& Hernandez A 2009 Minireview: defining the roles of the iodothyronine deiodinases: current concepts and challenges. Endocrinology 150 1097-1107. (doi:10.1210/en.2008-1588)

Stevenson TJ, Onishi KG, Bradley SP \& Prendergast BJ 2014 Cellautonomous iodothyronine deiodinase expression mediates seasonal plasticity in immune function. Brain, Behavior, and Immunity 36 61-70. (doi:10.1016/j.bbi.2013.10.008)

Suzuki S, Suzuki N, Mori J, Oshima A, Usami S \& Hashizume K 2007 micro-Crystallin as an intracellular 3,5,3'-triiodothyronine holder in vivo. Molecular Endocrinology 21 885-894. (doi:10.1210/me.2006-0403)

Visser WE, Friesema EC \& Visser TJ 2009 Transport of thyroxine and $3,3^{\prime}, 5$-triiodothyronine in human umbilical vein endothelial cells. Endocrinology 150 1552-1557. (doi:10.1210/en.2008-0627) http://joe.endocrinology-journals.org

DOI: $10.1530 / J O E-16-0423$
๑) 2017 Society for Endocrinology Printed in Great Britain 
Wajner SM, Goemann IM, Bueno AL, Larsen PR \& Maia AL 2011 IL-6 promotes nonthyroidal illness syndrome by blocking thyroxine activation while promoting thyroid hormone inactivation in human cells. Journal of Clinical Investigation 121 1834-1845. (doi:10.1172/ JCI44678)

Walsh KP \& Mills KH 2013 Dendritic cells and other innate determinants of T helper cell polarisation. Trends in Immunology 34 521-530. (doi:10.1016/j.it.2013.07.006)
Williams GR \& Bassett JH 2011 Deiodinases: the balance of thyroid hormone: local control of thyroid hormone action: role of type 2 deiodinase. Journal of Endocrinology 209 261-272. (doi:10.1530/JOE10-0448)

Zevenbergen C, Meima ME, Lima de Souza EC, Peeters RP, Kinne A, Krause G, Visser WE \& Visser TJ 2015 Transport of iodothyronines by human L-type amino acid transporters. Endocrinology $1564345-4355$. (doi:10.1210/en.2015-1140)

Received in final form 6 December 2016

Accepted 15 December 2016
Published by Bioscientifica Ltd. 